KatARZYNA KowALSKA

Uniwersytet Pedagogiczny w Krakowie

\title{
Możliwości oceny wpływu bezpośrednich inwestycji zagranicznych w handlu na urzeczywistnianie rozwoju lokalnego i regionalnego
}

Ekspansja międzynarodowych sieci handlowych na polskim rynku wynika bez watpienia z postępującego procesu koncentracji firm handlowych i ograniczonych możliwości dalszego rozwoju tych podmiotów na rynkach macierzystych. Dodatkowych impulsów do internacjonalizacji dostarcza tym korporacjom fakt niedorozwoju infrastruktury handlu detalicznego w naszym kraju, przy jednoczesnym dużym potencjale wzrostu popytu ludności.

Kilkunastoletni rozwój międzynarodowych sieci handlowych branży FMCG ${ }^{1}$ na polskim rynku wywołał na nim szereg istotnych zjawisk i zmian. Mają one zarówno charakter pozytywny, jak i negatywny. $Z$ jednej strony ekspansja ta i stopniowe przejmowanie rynku spożywczego przez zagraniczne sklepy wielkopowierzchniowe zmobilizowały polskich przedsiębiorców do poszukiwania rozwiązań przystających do nowych i trudniejszych warunków konkurencji ${ }^{2}$, z drugiej - upowszechniły zjawiska, które określane są jako nadużycia w zakresie uczciwej konkurencji, kontaktów handlowych, lokalizacji i nabywania gruntów pod budowę dużych obiektów handlowych.

W Polsce, a szczególnie w regionach, w których najchętniej lokalizują swoją działalność omawiane sieci (województwo śląskie, mazowieckie), rodzimi przedsiębiorcy muszą sprostać wyjątkowo ostrej konkurencji, rywalizując z licznymi i silnymi ekonomicznie korporacjami handlowymi. Taka sytuacja w poszczególnych miastach i regionach rodzi pytania (zarówno środowisk kupieckich, ekonomistów jak i niektórych polityków), czy tak silna koncentracja wielkopowierzchniowych obiektów handlowych (WOH) na tych terenach służy realizacji dobrze rozumianej polityki rozwoju, do której samorząd gminy został powołany zgodnie z ustawą z dnia 6 grudnia 2006 r. O zasadach prowadzenia polityki rozwoju (art. 3), czy służy poprawie jakości życia mieszkańców, do której zobowiązuje art. 9 ust. 4 ustawy z dnia 8 marca 1990 r. O samorzqdzie gminnym, czy w wyniku takich działań władze gminy wypełniają swój obowiązek wspierania rozwoju przedsiębiorczości poprzez tworzenie korzystnych warunków do podejmowania i wykonywania działalności gospodarczej, co

${ }^{1}$ Określenie FMCG (skrót od ang. Fast Moving Consumer Goods) oznacza produkty szybkorotujące, codziennego użytku. Należą do nich przede wszystkim artykuły spożywcze, kosmetyki, chemia gospodarcza.

${ }^{2}$ Ekspansja zagranicznych korporacji handlowych mobilizuje przede wszystkim działania integracyjne wśród polskich przedsiębiorców, co ma kluczowe znaczenie dla poprawy ich konkurencyjności na rynku. 
W szczególności dotyczy mikro- oraz małych i średnich przedsiębiorstw (art. 8 ust. 1 ustawy z dnia 2 lipca 2004 r. O swobodzie działalności gospodarczej). Podejmując próbę odpowiedzi na powyższe pytania, należy przede wszystkim rozstrzygnąć dwie podstawowe kwestie:

- Czy dostępne w Polsce dane statystyczne i informacje gospodarcze pozwalają ocenić oddziaływanie ZIB w handlu branży FMCG na rynek pracy w danym układzie lokalnym czy też regionalnym?

- Jak duże są wpływy i jaka tendencja występuje w zakresie płacenia podatków dochodowych przez międzynarodowe korporacje handlowe w porównaniu z udziałami w podatkach dochodowych sektora MŚP w województwie śląskim, najbardziej nasyconym w Polsce zagranicznymi placówkami detalicznymi (zob. IBRKiK, 2008, s. 109-117)?

W artykule postawiono następującą hipotezę: silny rozwój nowoczesnego handlu w Polsce, ze względu na skalę i zakres oddziaływania na krajowy handel, wymaga dostosowania w sposób szczegółowy i całościowy oficjalnej statystyki do dzisiejszych realiów polskiego rynku detalicznego branży FMCG.

\section{ROLA I ZNACZENIE EKSPANSJI ZAGRANICZNYCH KORPORACJI BRANŻY FMCG} DLA POLSKIEGO HANDLU

Silna ekspansja zachodnioeuropejskich sieci handlowych na polski rynek wywołuje liczne dyskusje na temat ich znaczenia w branży FMCG. Również w innych krajach Europy z powodu nasilających się tam procesów koncentracji w handlu detalicznym problem ten stał się obiektem zainteresowania ekonomistów i polityków. Przykładem tego może być Wielka Brytania, która po ocenie stopnia koncentracji handlu na własnym rynku wznowiła debate nad społeczno-gospodarczymi skutkami omawianego zjawiska (Stawicki 2005, s. 95). Także w Polsce problem zwiększenia kontroli nad funkcjonowaniem międzynarodowych sklepów wielkopowierzchniowych stał się częścią programów niektórych partii politycznych. Szybki i postępujący rozwój sieci międzynarodowych korporacji, dokonujący się w sposób organiczny w formie zagranicznych inwestycji bezpośrednich typu greenfield, jak również poprzez liczne fuzje, przejęcia i wspólne przedsięwzięcia, rodzi pytanie o ewentualną dominację tych podmiotów w ujęciu lokalnym i regionalnym względem pozostałych firm $\mathrm{z}$ branży handlu detalicznego.

Klasyczna teoria ekonomii wiąże siłę rynkową przede wszystkim z udziałami w rynku. Tymczasem zagraniczne sieci handlowe nie posiadają na rozdrobnionym krajowym rynku znaczących w nim udziałów. Świadczą o tym udziały największych firm handlowych w Polsce, jak również orzecznictwo Prezesa UOKiK, który dotychczas nie ograniczył koncentracji przedsiębiorstw reprezentujących badaną branżę. Z drugiej strony, znane są w praktyce liczne przykłady naruszania prawa przez omawiane sieci, mimo obowiązywania ustaw stanowiących prawne podstawy umów między dostawcami i przedsiębiorstwami handlowymi (Ustawa z dnia 23 kwietnia 1964 r. Kodeks Cywilny; Ustawa z dnia 12 czerwca 2003 r. o terminach zaplaty w transakcjach handlowych; Ustawa z dnia 16 lutego 2007 r. o ochronie konkurencji i konsumentów; Ustawa z dnia 16 kwietnia 1993 r. o zwalczaniu nieuczciwej konkurencji, 2003 r.).

Okazuje się bowiem, że międzynarodowe sieci uzyskują w praktyce zdecydowanie korzystniejsze warunki handlowe $\mathrm{w}$ transakcjach $\mathrm{z}$ dostawcami. 
Wyniki badań realizowane przez różne wyspecjalizowane w tym zakresie ośrodki potwierdzają, że zagraniczne sieci handlowe, wykorzystując przewagę w kontaktach z dostawcami, narzucają swoje wygórowane warunki współpracy, dopuszczając się czynów nieuczciwej konkurencji ${ }^{3}$. Wyraźnym przykładem takiej sytuacji jest postępowanie prowadzone w 2002 r. przez UOKiK, którego przedmiotem były warunki systemu dystrybucji jednego z krajowych dostawców FMCG, mającego prawie monopolistyczną pozycję na rynku. Stwierdzono wówczas liczne nadużycia sieci handlowych względem tak silnego dostawcy (Stawicki 2005, s. 96).

Do podstawowych przejawów siły rynkowej w kontaktach handlowych z dostawcami można zaliczyć (NIK, 2002, s. 21):

- narzucanie wzorców umów handlowych przez operatorów sieci detalicznych;

- nakłanianie polskich producentów do wysokich upustów 10-12\%;

- dyktowanie przez sieci warunków dostaw, w tym przerzucanie na dostawców kosztów transportu i magazynowania;

- wymuszanie organizacji akcji promocyjnych;

- obciążanie producentów kosztami niezamówionych przez nich promocji;

- przekraczanie terminów płatności (Dyś 2003, s. 644)

- umowne zastrzeganie i pobieranie od dostawców świadczeń pieniężnych za przyjęcie produktu do sklepu sieci (Szczepanowska-Kozłowska 2007, s. 117; Nestoruk 2007, s. 102$)^{5}$;

- imitację silnych marek producentów przez marki własne sieci handlowych (Domański 2001, s. $127-128)^{6}$.

${ }^{3}$ „Czynem nieuczciwej konkurencji jest działanie sprzeczne z prawem lub dobrymi obyczajami, jeżeli zagraża lub narusza interes innego przedsiębiorcy lub klienta”. Jest nim m.in. naśladownictwo produktów, utrudnianie dostępu do rynku.

${ }^{4}$ Praktyki wymuszania na producentach dostarczających towar długich okresów płatności przed nowelizacją ustawy o terminach zapłaty w transakcjach handlowych dotyczyły przeciętnie 45 dni, a często do 90 dni od daty dostawy. W praktyce skutkowało to sytuacją, w której słabsi ekonomicznie producenci kredytowali swoich zagranicznych partnerów. Natomiast w 2004 r. przeciętna długość rzeczywistego terminu zapłaty mieściła się w przedziale 30-44 dni. Przy czym w przypadku sieci dyskontowych faktyczny termin zapłaty był dłuższy od terminu zapisanego $\mathrm{w}$ umowie.

${ }^{5}$ Opłaty za wejście do sklepów sieciowych przybierają w praktyce różną postać: opłaty jednorazowej, pobieranej najczęściej z góry, opłaty za wprowadzenie towaru do sprzedaży, opłaty za pozostawienie towaru w sprzedaży przez określony czas i opłaty za wyeksponowanie towaru na określonym miejscu. Uzgodnienia stron w zakresie takich opłat mają charakter ustaleń w kwestiach marketingowych.

Sąd Najwyższy (SN) w wyroku z 26.01.2006 r. (II CK 378/05) uznał, że opłata za wejście do sklepu sieci handlowej jest świadczeniem, które jest niezgodne z art. 15 ust. 1 pkt 4 ustawy zakazującej nieuczciwej konkurencji (u.z.n.k.). Zastrzeganie dodatkowych opłat przez przedsiębiorcę za to, że towary znajdują się w sklepach danego przedsiębiorcy, utrudnia w sposób oczywisty dostęp do rynku, a przez to narusza dobre obyczaje handlowe. Taka umowa, zgodnie z orzeczeniem SN, jest sprzeczna z zasadami współżycia społecznego i jest nieważna.

Powyższe orzeczenie SN jest szeroko krytykowane w literaturze przedmiotu. Na przykład podkreśla się, że art. 15 ust. 1 pkt 4 u.z.n.k nie daje podstaw do wyłączenia swobody hipermarketów w dostarczaniu na rzecz swoich dostawców innych świadczeń niż tylko odbiór towaru i zapłata ceny, a zatem świadczeń wynikających z umowy sprzedaży. Przytacza się racje ekonomiczne, podnoszone przez sieci handlowe, że wprowadzenie nowego produktu do sprzedaży wiąże się dla tych sieci z pewnymi kosztami.

${ }^{6}$ Ta kategoria marek określana jest mianem kontramarek, czyli marek wprowadzanych w celu ,skontrowania” marki lidera. Imitacja marki lidera dotyczy doboru nazwy produktu, formy, wielkości, wzornictwa i kolorów opakowania. Tak duża zbieżność cech marketingowych ma prowadzić do zmylenia konsumenta. 
Wymienione praktyki, choć naganne, bardzo rzadko znajdują swój finał przed sądem. Producenci w obawie przed pogorszeniem lub zakończeniem współpracy z zagranicznymi sieciami handlowymi godzą się często na tego typu działania.

Tego rodzaju relacje sieci handlowych z dostawcami towarów skutkują naruszaniem zasad uczciwej konkurencji przez sprzedaż towarów w sklepach omawianych firm bez marży handlowej, a w skrajnych przypadkach poniżej ceny nabycia (NIK 2002, s. 21). Oznacza to, zgodnie z obowiązującą ustawą zakazującą nieuczciwej konkurencji, że zagraniczne sieci handlowe ograniczają dostęp do rynku nie tylko dostawcom towarów (pobieranie innych niż marża handlowa opłat za przyjęcie towaru do sprzedaży), ale również małym sklepom (sprzedaż bez marży handlowej) [art. 15 ust. 1 pkt 4 i ust. 3 ustawy z dnia 16 kwietnia 1993 r. O zwalczaniu nieuczciwej konkurencji]. Z drugiej strony - jak wynika z badań część producentów rekompensuje sobie gorsze warunki dostaw do zagranicznych sieci handlowych na słabszych ekonomicznie detalistach (polskich sklepach) (Kowalska, s. 203).

Stąd częste wnoszone również do polskiego organu monopolowego skargi drobnych polskich przedsiębiorstw na nieuczciwe warunki handlowe na krajowym rynku FMCG.

Przedstawiony wyżej problem nadużyć i konieczność zmiany regulacji handlu wielkopowierzchniowego są coraz częściej dostrzegane na rynkach zagranicznych. We Francji pojawiły się propozycje uzdrowienia konkurencji na rynku detalicznym i poprawy stosunków między detalistami i dostawcami. W Wielkiej Brytanii propozycje zmian są wynikiem badania prowadzonego w ostatnich latach na rynku detalicznym przez Komisję ds. Konkurencji. Ze śledztwa wynika, że w znaczącej liczbie obszarów lokalnych wpływ wielkich detalistów wyklucza możliwość zdrowej konkurencji i eliminuje niezależnych detalistów („Handel” 2008, nr 9, s. 10).

Z drugiej strony konsekwencje napływu inwestycji zagranicznych do omawianej branży i powstałe w ich efekcie nowoczesne formy dystrybucji wywierają wpływ na zachowanie się polskich sklepów detalicznych. Wyzwaniem strategicznym staje się dla nich sprostanie rosnącej konkurencji poprzez wdrażanie innowacyjnych rozwiązań, umożliwiających dostosowanie krajowych firm do jakościowych przemian na rynku spożywczym w Polsce. Zmiany te nie dotyczą obecnie jedynie nowoczesnych form sprzedaży, co miało miejsce w początkowym okresie ekspansji międzynarodowych korporacji na naszym rynku, ale opierają się na rozbudowanej strategii premiowej, odróżniającej daną sieć od jej konkurentów. Kluczowe znaczenie w tej konkurencji pełni szeroka oferta produktów wysokiej jakości po niskiej cenie, dogodna lokalizacja, atrakcyjne promocje, nowoczesność, przejrzystość i wygoda sklepu oraz fachowa i przyjazna obsługa. Nie bez znaczenia są również usługi dodatkowe, które pomagają umocnić lojalność klientów względem sieci i mogą być również źródłem dochodów dla detalistów. Te i inne atuty, oferowane we wszystkich sklepach danej sieci, mają istotny wpływ na kształtowanie jej wizerunku, a w konsekwencji na wybór przez klienta miejsca dokonywania zakupów.

Wyzwaniom tym, ze względu na niewielkie możliwości finansowe polskich przedsiębiorstw, służą różne formy integracji (przede wszystkim grupy zakupowe, sieci franczyzowe) charakteryzujące branżę spożywczą. 


\section{ODDZIAŁYWANIE ZAGRANICZNYCH SIECI HANDLOWYCH NA RYNEK PRACY - EMPIRYCZNA WERYFIKACJA NA PRZYKŁADZIE WOJEWÓDZTWA ŚLĄSKIEGO}

W 2006 r. w województwie śląskim blisko 18\% ogółu pracujących absorbował handel - w handlu blisko $67 \%$ było zatrudnionych w mikroprzedsiębiorstwach (do 9 osób pracujących), 17,5\% w małych (10-49 osób), blisko 12\% w średnich (50-249) i 4,1\% w dużych (250 osób i więcej) [GUS]. A zatem przedsiębiorstwa mikro były dominującym pracodawcą w handlu.

Na Śląsku w latach 2002-2007 udział pracujących w przedsiębiorstwach handlowych z kapitałem zagranicznym w łącznej liczbie pracujących w handlu nie przekroczył 3\% (w 2002 r. - 2.8\%, w 2006 r. zmniejszył się do 2,3\%, a w 2007 r. wyniósł 2,5\%) [GUS].

Zagraniczne przedsiębiorstwa handlowe w województwie śląskim nie są zatem znaczącym pracodawca, a raczej ich rola $\mathrm{w}$ omawianym zakresie jest symboliczna, mimo że przyrost zatrudnienia w tych przedsiębiorstwach na omawianym obszarze w $2007 \mathrm{r}$. w stosunku do 2002 wyniósł ponad 43\% (w stosunku do 2006 r. blisko 27\%).

Spośród różnych skutków obecności zagranicznych firm handlowych na polskim rynku oddziaływanie na rynek pracy jest najmniej rozpoznane. Do najważniejszych przyczyn takiej sytuacji zalicza się wielość czynników kształtujących rynek pracy (np. stan koniunktury gospodarczej, politykę państwa, postęp technologiczny) oraz - co bardzo istotne - skromne dane statystyczne niedostosowane do badania wpływu handlu na rynek pracy.

W literaturze przedmiotu można jednak odnaleźć informacje na ten temat. Według obliczeń dokonanych w latach 90. przez francuskich naukowców, jedno miejsce pracy w supermarkecie powoduje likwidację 3-4 miejsc w handlu tradycyjnym. Podobne wnioski można znaleźć w polskiej literaturze. Problem polega na tym, że autorzy tych ustaleń z reguły nie ujawniają założeń i metod przyjmowanych w tych szacunkach.

W literaturze zagranicznej podkreśla się jednak, że w większości europejskich państw nastąpił spadek liczby sklepów detalicznych wraz z rozwojem nowoczesnego kanału dystrybucji (NKD) ${ }^{7}$. W Polsce natomiast, według danych AC Nielsen, na krajowym rynku odnotowuje się powolny, ale systematyczny spadek małych sklepów spożywczych (poniżej $50 \mathrm{~m}^{2}$ ) (AC Nielsen 2007, s. 8), w województwie śląskim w sekcji handel i naprawy liczba pracujących w przedsiębiorstwach mikro zmniejszyła się o 3,454 w $2008 \mathrm{r}$. w stosunku do 2007 r. [GUS].

Trudno na podstawie powyższych danych jednoznacznie wyrokować o przyczynach zmian na rynku pracy w województwie śląskim, ale nie można również tych danych pomijać w podjętym temacie.

\section{KWESTIA PŁACENIA PRZEZ ZAGRANICZNE WOH PODATKÓW DOCHODOWYCH W PORÓWNANIU Z UDZIAŁAMI W PODATKACH DOCHODOWYCH SEKTORA MŚP - EMPIRYCZNA WERYFIKACJA NA PRZYKŁADZIE WOJEWÓDZTWA ŚLĄSKIEGO}

Zgodnie z Rozporządzeniem Ministra Finansów z dnia 14 czerwca 2006 r. W sprawie szczegótowej klasyfikacji dochodów, wydatków, przychodów i rozchodów oraz środków pochodzacych z źródeł zagranicznych nie ma obowiązku klasyfikacji wpływu z podatków

\footnotetext{
${ }^{7} \mathrm{NKD}$ to hipermarkety, supermarkety i sklepy dyskontowe.
} 
dochodowych sektora MŚP i dużych przedsiębiorstw czy korporacji. W związku z tym tego rodzaju informacje nie są opracowywane we właściwych instytucjach. Nie są dostępne również w Regionalnej Izbie Obrachunkowej, instytucji sprawującej nadzór nad działalnością jednostek samorządu terytorialnego w zakresie spraw finansowych.

Niemniej jednak pewnych informacji na temat płacenia przez zagraniczne WOH podatków dochodowych dostarcza raport Najwyższej Izby Kontroli (NIK) z 2002 r. Na zlecenie NIK organy kontroli skarbowej wszczęły w omawianym zakresie postępowanie w następujących spółkach: Carrefour, Jeronimo Martins Dystrybucja, Ahold, Tesco Geant. We wszystkich badanych przypadkach stwierdzono wówczas nieprawidłowości w deklarowaniu podstaw opodatkowania podatkiem dochodowym od osób prawnych.

Podmioty objęte kontrolą wykazywały straty w działalności gospodarczej i z tego powodu nie uiszczały podatku dochodowego od osób prawnych. Straty te powstały przede wszystkim w wyniku wysokich odpisów amortyzacyjnych dokonywanych od środków trwałych oraz wysokich kosztów finansowych, tj. odsetek od zaciągniętych kredytów (NIK 2002, s. 43-47).

Należy również podkreślić, że zgodnie z art. 17 ustawy Ordynacja podatkowa właściwość miejscową organów podatkowych ustala się według adresu siedziby podatnika. W praktyce zatem silnie rozwijające się na terenie województwa śląskiego zagraniczne sieci handlowe podatek dochodowy płacą poza jego terytorium. Dla przykładu, siedzibą Tesco jest województwo małopolskie; sieci Carrefour, Auchan i Real - mazowieckie, Lidl - wielkopolskie.

Aby w pełni zobrazować sytuację, a dokładniej możliwości oceny wpływu zagranicznych inwestycji handlowych branży FMCG na polski rynek, warto podjąć próbę odpowiedzi na pytanie, jaka część zysków międzynarodowych korporacji handlowych jest przedmiotem transferu za granicę, a jaka jest reinwestowana w Polsce? Informacje o dochodach i reinwestowanych zyskach zagranicznych inwestorów bezpośrednich działających na terenie Polski można odnaleźć w corocznym raporcie NBP - „Zagraniczne inwestycje bezpośrednie w Polsce". Należy zaznaczyć, że dane w przedmiotowym raporcie nie odnoszą się bezpośrednio do branży FMCG, a jedynie (w tym przypadku) do sekcji handlu i naprawy (w ramach której klasyfikuje się działalność międzynarodowych sieci branży FMCG). Należy w tym miejscu zauważyć, że według Polskiej Klasyfikacji Wyrobów i Usług przytoczona sekcja jest bardzo pojemna, obejmuje bowiem poza omawianą branżą m.in. sprzedaż paliw, samochodów i ich naprawę. NBP nie publikuje zatem ani też nie opracowuje danych dotyczących wybranej branży, a jedynie zbiorcze dane przygotowane według obowiązujących standardów międzynarodowych. NBP nie opracowuje również danych z podziałem na województwa. Trudno więc na podstawie dostępnych danych NBP wnioskować o skali reinwestowanych zysków w Polsce przez korporacje handlowe branży FMCG, a tym bardziej w wybranym województwie.

Warto również zwrócić uwagę na brak unifikacji poszczególnych kanałów dystrybucji, jak również nieuwzględnianie w sprawozdawczości niektórych form sprzedaży detalicznej. Nieuwzględnione w statystyce GUS sklepy dyskontowe mają duże znaczenie we wzroście sprzedaży w Polsce produktów FMCG („Handel” 2008, nr 12, s. 45).

Ponadto zachodnie sieci handlowe inwestują w sklepy, których według klasyfikacji GUS nie można już zaliczyć do wielkopowierzchniowych obiektów, a równie silnie oddziaływują na rynek (jak WOH), a mianowicie w tzw. sklepy sąsiedzkie, np. Globi Express 
(przekształcane w Carrefour Express: 120-300 m²) i sklepy typu convenience ${ }^{8}$, np. Carrefour 5 minut $\left(80-500 \mathrm{~m}^{2}\right)$ i Tesco Express (250-300 m²) [„Handel” 2007, nr 18, s. 8; „Handel” 2008 , nr 2, s. 6). Sklepy te działają z logo wielkich i znanych sieci na obszarach, gdzie ich obecność była do tej pory słabo zaznaczona.

\section{WNIOSKI KOŃCOWE}

Na podstawie przeprowadzonej powyżej analizy należy zwrócić uwagę na konieczność dostosowania oficjalnej statystyki do dzisiejszych realiów polskiego rynku detalicznego branży FMCG. Jest to kluczowa kwestia dla precyzyjnej oceny rozwoju tego rynku oraz śledzenia wpływu zagranicznych korporacji handlu detalicznego na sytuację w omawianej branży, a przede wszystkim na warunki urzeczywistniania rozwoju na poziomie lokalnym czy regionalnym. Dzisiaj takie analizy są utrudnione ze względu na skromne dane statystyczne, niedostosowane do badania wpływu handlu na rynek pracy; brak danych odnośnie płacenia przez zagraniczne WOH podatków dochodowych w porównaniu z udziałami w podatkach dochodowych sektora MŚP, brak danych szczegółowych odnośnie reinwestowanych zysków BIZ branży FMCG, brak unifikacji poszczególnych kanałów dystrybucji, jak również nieuwzględnianie w sprawozdawczości niektórych form sprzedaży detalicznej.

Konieczność dostosowania oficjalnej statystyki do dzisiejszych realiów polskiego rynku detalicznego wynika z roli i znaczenia ekspansji zagranicznych podmiotów dla polskiego handlu, a ostatecznie dla rynku pracy i budżetów lokalnych, które stanowią główne obszary polityki rozwoju lokalnego czy regionalnego.

Duża koncentracja międzynarodowych korporacji handlowych wywołuje silną presję konkurencyjną na rynku wewnętrznym. Przewaga rynkowa tych podmiotów ma swoje źródło w akceptowanej ofercie, skali działania, potencjale finansowym i stosowanych strategiach marketingowych (Kłosiewicz-Górecka 2007, s. 197). Komisja Europejska (KE) zwraca również uwagę na potęgowanie siły sieci handlowych poprzez tworzenie przez te firmy wspólnych grup zakupowych i uczestnictwo w aliansach strategicznych (Stawicki 2005, s. 99). Wszystkie te praktyki sprawiają że międzynarodowe sieci handlowe egzekwują nadmierne wsparcie producentów krajowych (ale również międzynarodowych) do finansowania polityki niskich cen w sklepach sieci. W konsekwencji osiągają zdecydowaną przewagę rynkową wobec polskich, w niewielkim stopniu jeszcze zintegrowanych sklepów detalicznych.

Postulat dostosowania oficjalnej statystyki do realiów polskiego rynku umacnia również analiza skali i dynamiki napływu zagranicznych inwestycji do branży FMCG w Polsce. W 2005 r. wyniosły one 5,816,54 mln USD i były wyższe od inwestycji z 1996 r. o ponad 2,296\% (Kowalska, s. 63-64). Wprawdzie brak danych o wartości inwestycji zagranicznych w późniejszych latach, ale ilościowy wzrost otwieranych w naszym kraju zagranicznych sklepów wielkopowierzchniowych potwierdza powyższy wniosek.

\footnotetext{
${ }^{8}$ Moda na segment convenience dotarła do Polski z rozwiniętych krajów zachodnich, gdzie rynek dla sklepów wielkopowierzchniowych okazał się już tak nasycony, że firmy detaliczne były zmuszone do znalezienia innych metod dotarcia do klienta. Sektor ten w Polce jest słabo rozwinięty, ale perspektywy dla niego są bardzo obiecujące.
} 


\section{Literatura}

AC Nielsen, 2007, Shopper Trends 2007, Warszawa (dokument elektroniczny).

Domański T., 2001, Strategie marketingowe dużych sieci handlowych, Wydawnictwo Naukowe PWN, Warszawa-Łódź.

Dyś T., 2003, Nieuczciwa konkurencja: opłaty za przyjęcie towaru do sprzedaży, Monitor Prawniczy, nr 14.

Handel wewnętrzny w Polsce w 2007 roku. Raport roczny, Instytut Badań Rynku, Konsumpcji i Koniunktur, 2008, Warszawa.

Informacja o wynikach kontroli lokalizacji dużych obiektów handlowych (super i hipermarketów), 2002, NIK, Białystok.

Kowalska K., Rozwój sieci polskich sklepów detalicznych jako sposób ograniczania siły rynkowej międzynarodowych korporacji handlowych. Empiryczna weryfikacja na przykladzie województwa ślaskiego, (niepublikowana rozprawa doktorska).

Nestoruk I.B., 2007, Opłaty za przyjęcie towarów do sieci sklepów a ustawa o zwalczaniu nieuczciwej konkurencji, Glosa, $\mathrm{nr} 1$.

Rozporzqdzenie Ministra Finansów z dnia 14 czerwca 2006 r. w sprawie szczegółowej klasyfikacji dochodów, wydatków, przychodów i rozchodów oraz środków pochodzacych z źródet zagranicznych, Dziennik Ustaw Rzeczypospolitej Polskiej, 2006 r., nr 107, poz. 726.

Stawicki E., 2005, Konkurencja w handlu, [w:] Ochrona konkurencji i konsumentów w Polsce i Unii Europejskiej (studia prawno-ekonomiczne), red. C. Banasiński, UOKiK, Warszawa .

Szczepanowska-Kozłowska K., 2007, Pobieranie innych niż marża handlowa opłat za przyjęcie towaru do sprzedaż, Glosa, $\mathrm{nr} 2$.

Ustawa z dnia 12 czerwca 2003 r. o terminach zapłaty w transakcjach handlowych, Dziennik Ustaw Rzeczypospolitej Polskiej, 2003 r., nr 139, poz. 1323.

Ustawa z dnia 16 kwietnia 1993 r. o zwalczaniu nieuczciwej konkurencji, Dziennik Ustaw Rzeczypospolitej Polskiej, 2003 r., nr 153, poz. 1503 ze zm.

Ustawa z dnia 16 lutego 2007 r. oochronie konkurencji i konsumentów, Dziennik Ustaw Rzeczypospolitej Polskiej, 2007 r., nr 50, poz. 331.

Ustawa z dnia 2 lipca 2004 r. o swobodzie działalności gospodarczej, Dziennik Ustaw Rzeczypospolitej Polskiej, 2004 r., nr 173, poz. 1807 ze zm.

Ustawa z dnia 23 kwietnia 1964 r. kodeks cywilny, Dziennik Ustaw Rzeczypospolitej Polskiej, 1964 r., nr 16, poz. 93.

Ustawa z dnia 29 sierpnia 1997 r. Ordynacja podatkowa, Dziennik Ustaw Rzeczypospolitej Polskiej, 2005 r., $\mathrm{nr} 8$, poz. 60.

Ustawa z dnia 6 grudnia 2006 r. o zasadach prowadzenia polityki rozwoju, Dziennik Ustaw Rzeczypospolitej Polskiej, 2006 r., nr 227, poz. 658.

Ustawa z dnia 8 marca 1990 r. o samorzadzie gminnym, Dziennik Ustaw Rzeczypospolitej Polskiej, 1990 r., nr 16, poz. 95 ze zm.

W imię konkurencji, 2008, Handel, nr 9.

Zagraniczne inwestycje w handlu na rynkach lokalnych, red. U. Kłosiewicz-Górecka 2007, Wydawnictwo PWE, Warszawa 


\section{The possibilities of estimating the influence of direct foreign investments on trade in local and regional development's aspect}

The article consist of introduction, three essential paragraphs and conclusion. In the first paragraph the role of foreign corporations' expansion of FMCG branch in Polish trade aspect is discussed. The second paragraph concerns the estimation of the influence of foreign trade networks on labour markets (based on Silesian region's case). The payment of income taxes by corporations in comparison to participation of MSP sector in income taxes' shares is discussed in the third paragraph. The conclusion explains why it is difficult to analyze the influence of direct foreign investments on trade in local and regional development's aspect. There is not enough data adapted to analyze the trade influence on labour market and local budget.

dr Katarzyna Kowalska

Uniwersytet Pedagogiczny w Krakowie

Instytut Politologii

e-mail:kasiak@up.krakow.pl 